\title{
ANALISIS PERBANDINGAN PENDANAAN ASET TETAP ALTERNATIF LEASING DENGAN PINJAMAN BANK DALAM EFISIENSI PAJAK PENGHASILAN BADAN (STUDI KASUS PADA PT CAHAYA GASDOM)
}

\author{
Wiwik Budiarti $^{*}$ dan Fadilah Dian Hidayati ${ }^{* *}$
}

\begin{abstract}
ABSTRAK
Besarnya dana yang harus disiapkan merupakan alasan utama perusahaan memilih sumber dana ekternal dalam membiayai pengadaan aset tetapnya. Pemenuhan kebutuhan pendanaan dalam pengadaan aset tetap dapat dilakukan dengan cara sewa guna usaha (leasing) atau dengan pinjaman bank. Kedua sumber pendanaan tersebut mampu membantu perusahaan tanpa mengganggu aktivitas operasional perusahaan yang membutuhkan modal. Penelitian ini bertujuan untuk mengetahui perbedaan present value cash outflow dan berapa besar efisiensi pajak penghasilan badan pendanaan atas aset tetap aternatif leasing dengan pinjaman bank pada PT Cahaya Gasdom dengan menggunakan data primer dan sekunder. Metode analisis yang digunakan adalah analisis perbandingan present value cash outflow dan efisiensi pajak penghasilan badan. Hasil penelitian mengungkapkan fakta bahwa (1) Present value cash outflow alternatif leasing lebih kecil dari pada pinjaman bank atas penyusutan menggunakan metode garis lurus maupun penyusutan yang menggunakan metode saldo menurun, selisih dari Present value cash outflow tersebut adalah sebesar Rp 46.819.503 dan Rp 10.461.410. (2) Penghematan pajak pendanaan alternatif leasing lebih besar daripada alternatif pinjaman bank atas penyusutan menggunakan metode garis lurus maupun penyusutan yang menggunakan metode saldo menurun, selisih dari penghematan pajak tersebut adalah sebesar Rp 44.005.075 dan Rp 5.771.872.
\end{abstract}

Kata kunci: Pendanaan Aset Tetap dan Efisiensi Pajak Penghasilan

\begin{abstract}
The amount of funds that must be prepared is the main reason for the company to chose an external source of funds to finance the procurement of its fixed assets. The fulfillment of funding requirements in the procurement of fixed assets can be done by way of lease (leasing) or by bank loans. Both of these funding sources to help companies without disrupting the operational activities of companies that need capital. This study aims to determine the differences present value cash outflow and how much the efficiency of the corporate income tax on fixed assets financing leasing aternatif with a bank loan in PT Cahaya Gasdom using primary and secondary data. The analytical method that used is a comparative analysis of the present value of cash outflow and efficiency of corporate income tax. Results of the study revealed the fact that (1) Present value cash outflow leasing alternative is less than the bank loans on depreciation using the straight-line method and depreciation using the declining balance method, the difference between the present value of the cash outflow amounted to Rp 46,819,503 and Rp 10,461 .410. (2) Tax savings alternative financing leasing is greater than the alternative of a bank loan, depreciation using the straight-line method and depreciation using the declining balance method, the difference in tax savings amounted to $R p$ 44,005,075 and Rp 5,771,872.
\end{abstract}

Key words: Financing Fix Asset and Income Tax Efficiency

\footnotetext{
${ }^{*}$ Dosen Tetap Fakultas Ekonomi Universitas Pakuan

${ }^{* *}$ Mahasiswa Fakultas Ekonomi Universitas Pakuan
} 


\section{Pendahuluan}

Pengembangan dan perluasan usaha dapat dilakukan dengan cara penambahan aset tetap atau investasi. Aktivitas ini membutuhkan dana yang besar. Kebutuhan akan dana tersebut dapat diperoleh dengan beberapa cara, namun yang perlu diperhatikan adalah cara perusahaan mengelola dan menghitung alternatif-alternatif pemenuhan dana demi menghindari pengeluaran perusahaan yang terlalu besar.

Besarnya dana yang harus disiapkan merupakan alasan utama perusahaan memilih sumber dana ekternal dalam membiayai pengadaan aset tetapnya. Pemenuhan kebutuhan pendanaan dalam pengadaan aset tetap dapat dilakukan dengan cara sewa guna usaha (leasing) atau dengan pinjaman bank. Kedua sumber pendanaan tersebut mampu membantu perusahaan tanpa mengganggu aktivitas operasional perusahaan yang membutuhkan modal.

Sewa guna usaha (leasing) dikenal di Indonesia pada tahun 1974 melalui Surat Ketetapan

Bersama 3 Menteri, yaitu: Menteri Keuangan, Menteri Perdagangan, dan Menteri Perindustrian dengan No. Kep122/MK/2/1974,No32/M/SK/2.1974, dan No.30/Kbp/I/1974 tertanggal 7 Pebruari 1974 tentang Perizinan Usaha Leasing.

Berdasarkan PSAK No. 30 tentang Standar Akuntansi Sewa Guna Usaha, disebutkan bahwa sewa guna usaha terdiri dari dua jenis, yaitu sewa pembiayaan dan sewa operasi. Sewa pembiayaan adalah sewa yang mengalihkan secara substansial seluruh risiko dan manfaat yang terkait dengan kepemilikan suatu aset. Hak milik pada akhirnya dapat dialihkan, dapat juga tidak dialihkan. Sedangkan sewa operasi adalah sewa selain sewa pembiayaan.
Aset yang berasal dari leasing dengan hak opsi boleh disusutkan oleh penyewa (lessee) menjadi beban penyusutan. Perlakuan berdasarkan PSAK berbeda dengan perlakuan berdasarkan ketentuan perpajakan. Dimana dalam ketentuan perpajakan menurut Keputusan Menteri Keuangan RI No. 1169/KMK.01/1991 bahwa selama masa sewa guna usaha, pihak lessee tidak boleh melakukan penyusutan atas aset yang disewagunausahakan, sampai saat lessee menggunakan opsi untuk membeli aset. Setelah lessee menggunakan opsi untuk membeli aset, lessee dapat melakukan penyusutan dengan dasar penyusutannya adalah nilai sisa aset tersebut. Dengan adanya perbedaan tersebut maka akan menimbulkan koreksi fiskal yang akan berdampak pada besarnya pajak perusahaan.

Kredit (pinjaman) merupakan kemampuan untuk melaksanakan suatu pemberian atau mengadakan suatu pinjaman dengan suatu janji pembayarannya akan dilakukan pada suatu jangka waktu yang di sepakati. Pengertian kredit (pinjaman) menurut pasal 1 ayat 11 UU No.10 tahun 1998 tentang Perbankan yang dikutip oleh Syamsu Iskandar $(2013,364)$

Kredit adalah penyediaan uang atau tagihan yang dapat dipersamakan dengan itu, berdasarkan persetujuan atau kesepakatan pinjam meminjam antara bank dengan pihak lain yang mewajibkan pihak peminjam untu melunai utangnya setelah jangka waktu tertentu dengan penerimaan bunga.

Pada pinjaman bank mempunyai pengaruh pajak yang berbeda sebagai akibat dari pembebanan bunga dan depresiasi, sedangkan pada leasing peraturan perpajakan memperbolehkan pembiayaan sewa guna usaha dengan hak opsi (financial lease) semua angsuran berikut bunga leasing dapat 
diakui sebagai biaya untuk mengurangi penghasilan bruto.

Pendanaan leasing dan pinjaman bank merupakan sumber dana eksternal yang mempunyai karakteristik cash flow serupa. Cash flow dari kedua pendanaan tersebut sama-sama bersifat anuited. Pengadaan aset tetap diperlukan pemikiran dan perhitungan yang cermat, supaya keputusan pendanaan yang dipilih bisa menguntungkan atau meminimalisasi biaya yang dikeluarkan perusahaan.

Bagi perusahaan dalam menjalankan praktik bisnis, pajak merupakan beban yang harus ditekan karena pajak dapat mengurangi laba bersih mereka. Oleh karena itu, perusahaan perlu membuat strategistrategi tertentu untuk mengurangi beban pajak agar dapat mengoptimalkan laba.

Sebagai acuan dalam penelitian ini dikemukakan hasil penelitian yang dilakukan oleh Hidayatullah, tahun 2010 dengan judul Analisis Perbandingan Perencanaan Pajak Untuk Pengadaan Aktiva Dengan Cara Sewa Guna Usaha (Leasing) Dan Pembelian Tunai Dalam Rangka Penghematan Pajak pada PT. Els Indonesia Prima. Penelitian tersebut menggunakan metode analisis deskriptif. Hasil penelitian tersebut menunjukan bahwa ada perbedaan yang signifikan antara pengadaan aset secara leasing khususnya pada jenis financial lease jika dibandingkan dengan membeli aset secara tunai. Hal ini disebankan karena adanya biaya leasing atau lease fee dan biaya penyusutan pada alternatif lease yang dapat dibebankan (deductable expenses) dengan jumlah yang lebih besar.

Dalam penelitian yang dilakukan oleh Irwan, tahun 2011 dengan judul Analisis Komparasi Kredit Bank Versus Financial Leasing Untuk Mengefisiensi Beban Pajak Atas Perolehan Aktiva Tetap (Studi Kasus Di Perusahaan
Percetakan). Penelitian tersebut menggunakan metode analisis komparasi. Hasil penelitian menunjukan bahwa pembiayaan leasing lebih menguntungkan dibandingkan dengan pembiayaan kredit bank.

Terdapat perbedaan dengan penelitian terdahulu diantaranya lokasi yang diigunakan, dalam penelitian ini lokasi yang digunakan adalah PT Cahaya Gasdom, variabel yang digunakan, dalam penelitian ini tidak mengunakan alternatif pembelian tunai, serta tahun penelitian yang berbeda. Sedangkan persamaan dalam penelitian ini variabel yang digunakan adalah pendanaan alternatif leasing, pinjaman bank dan pajak penghsilan badan.

PT Cahaya Gasdom yang beralamat di Jalan Raya Kemang No. 387, Kecamatan Kemang, Kelurahan Kemang, Kabupaten Bogor, merupakan perusahaan yang bergerak di bidang pemasaran dan distribusi gas elpiji $3 \mathrm{~kg}$. Perusahaan berencana untuk menambah aset tetap berupa kendaraan truk untuk mengoptimalkan distribusi gas elpiji 3 $\mathrm{kg}$.

Adapun tujuan yang hendak dicapai dalam penelitian ini atas permasalahan di atas, yaitu sebagai berikut:

1. Untuk mengetahui penerapan kebijakan pendanaan atas aset tetap pada PT. Cahaya Gasdom.

2. Untuk mengungkapkan perbedaan present value cash outflow pendanaan atas aset tetap aternatif leasing dengan pinjaman bank pada PT Cahaya Gasdom.

3. Untuk mengetahui berapa besar efisiensi pajak penghasilan badan pada PT Cahaya Gasdom.

\section{Landasan Teori \\ 2.1. Aset Tetap}


Sesuai dengan PSAK Nomor 16 (Revisi 2011) tentang Aset Tetap dan Aset Lain-Lain, pengertian aset tetap adalah aset berwujud yang diperoleh dalam bentuk siap pakai atau dengan dibangun lebih dahulu, yang digunakan dalam operasi perusahaan, tidak dimaksudkan untuk dijual dalam rangka kegiatan normal perusahaan dan mempunyai masa manfaat lebih dari satu tahun. Pemrolehan aset tetap dapat melalui sewa guna usaha (leasing), yaitu suatu kontrak antara lessor (pemilik barang modal) dengan lesse (pengguna barang modal) di mana lessor memberikan hak kepada lesse untuk menggunakan barang modal selama jangka waktu tertentu, dengan suatu imbalan berkala dari lesse yang besarnya tergantung dari perjanjian antara lessor dan lesse. Lesse dapat diberikan hak opsi untuk membeli barang tersebut pada akhir masa kontrak (Suandy, 2008).

\subsection{Efisiensi Pajak Penghasilan}

Strategi untuk mengefisiensikan beban PPh Badan, yaitu (Rumuy, 2013):

1. Pemilihan alternatif dasar pembukuan, basis kas atau akrual;

2. Pengelolaan transaksi yang berkaitan dengan pemberian kesejahteraan kepada karyawan;

3. Pemilihan metode penilaian persediaan;

4. Pemilihan sumber dana dalam pengadaan aset tetap;

5. Pemilihan metode penyusutan aset tetap dan amortisasi aset tidak berwujud;

6. Transaksi yang berkaitan dengan pemungutan pajak (Withholding tax);

7. Optimalisasi pengkreditan pajak yang telah dibayar;
8. Permohonan penurunan pembayaran angsuran masa $(\mathrm{PPh}$ Pasal 25 bulanan);

9. Pengajuan Surat Keterangan Bebas (SKB) PPh Pasal 22 dan 23;

10. Rekonsiliasi SPT; dan

11. Penyertaan modal pada perseroan terbatas dalam negeri.

\section{Metodologi Penelitian}

Berikut tahapan analisis data dalam penelitian ini:

1. Pengadaan aset tetap
a. Jenis dan jumlah aset tetap
b. Penentuan pengadaan aset tetap
c. Besarnya kebutuhan dana

2. Pendanaan leasing
a. Besarnya angsuran pokok leasing
b. Skedul pembayaran pokok dan bunga pendanaan leasing
c. Menentukan biaya yang boleh dikurangkan dari PPh badan.
d. Present Value terhadap cash outflow leasing

3. Pendanaan pinjaman bank
a. Besarnya angsuran pokok pinjaman bank
b. Skedul pembayaran pokok dan bunga pendanaan pinjaman bank
c. Menghitung penyusutan menurut perpajakan
d. Menentukan biaya yang boleh dikurangkan dari PPh badan.
e. Present Value terhadap cash outflow pinjaman bank

\section{Pemilihan sumber pendanaan}

Memilih alternatif pendanan yang menguntungkan bagi perusahaan melalui metode perbandingan biaya arus kas keluar sekarang, dengan membandingkan cash outflow sumber pendanaan leasing dengan cash outflow pendanaan pinjaman bank. Sumber pendanaan yang memiliki present 
value cash outflow yang paling kecil dan alternatif pendanaan dengan biaya yang boleh dikurangkan terbesar dalam perhitungan $\mathrm{PPh}$ yang menjadi rekomendasi untuk digunakan oleh PT Cahaya Gasdom.

\section{Hasil dan Pembahasan}

Rencana PT Cahaya Gasdom dalam pengadaan aset tetap guna melakukan ekspansi atau perluasan usaha dihadapkan pada pendanaan alternatif leasing dan pinjaman bank.
Data dan informasi mengenai kedua alternatif pendanaan diolah sehingga menghasilkan perhitungan yang dapat digunakan sebagai pertimbangan dalam pemilihan alternatif sumber pendanaan dalam pengadaan aset tetap yaitu melalui perbandingan cash outflow dan biaya yang boleh dikurangkan antara kedua sumber pendanaan. Perbandingan cash outflow antara pendanaan alternatif leasing dan pinjaman bank telah diketahui melalui perhitungan total present value cash outflow.

Tabel 1

Selisih Total Present Value Cash Outflow

(Penyusutan Metode Garis Lurus)

\begin{tabular}{|c|c|}
\hline Sumber Pendanaan & $\begin{array}{c}\text { Total Present Value } \\
\text { Cash Outflow }\end{array}$ \\
\hline Leasing & $\mathrm{Rp} \mathrm{394.982.202}$ \\
\hline Pinjaman Bank & $\mathrm{Rp} \mathrm{441.801.705}$ \\
\hline Selisih & $\mathrm{Rp} \mathrm{46.819.503}$ \\
\hline
\end{tabular}

Sumber: Data diolah Penulis, 2015.

Perbandingan total present value cash outflow alternatif leasing lebih kecil dari pada pinjaman bank atas penyusutan metode garis lurus sehingga pendanaan alternatif leasing lebih menguntungkan dari pada pendanaan alternatif pinjaman bank. PT Cahaya Gasdom akan menghemat pengeluaran sebesar $\mathrm{Rp}$ 46.819.503 apabila menggunakan pendanaan alternatif leasing.

Tabel 2

Selisih Total Present Value Cash Outflow

(Penyusutan Metode Saldo Menurun)

\begin{tabular}{|c|c|}
\hline Sumber Pendanaan & $\begin{array}{c}\text { Total Present Value } \\
\text { Cash Outflow }\end{array}$ \\
\hline Leasing & $\mathrm{Rp} \mathrm{394.982.202}$ \\
\hline Pinjaman Bank & $\mathrm{Rp} \mathrm{405.443.612}$ \\
\hline Selisih & $\mathrm{Rp} 10.461 .410$ \\
\hline
\end{tabular}

Sumber: Data diolah Penulis, 2015.

Berdasarkan tabel tersebut, perbandingan total present value cash outflow alternatif leasing lebih kecil dari pada pinjaman bank atas penyusutan metode saldo menurun sehingga pendanaan alternatif leasing lebih menguntungkan dari pada pendanaan alternatif pinjaman bank atas penyusutan metode saldo menurun. PT Cahaya Gasdom akan menghemat pengeluaran 
sebesar Rp $\quad 10.461 .410 \quad$ apabila menggunakan pendanaan alternatif leasing.

Pendanaan alternatif leasing lebih menguntungkan dari pada alternatif pinjaman bank, baik mengunakan penyusutan metode garis lurus maupun metode saldo menurun. Hal ini dipengaruhi oleh beberapa faktor diantaranya perbedaan angsuran, bunga pinjaman, perbedaan pengaruh pajak serta kewajiban perusahaan membayar hak opsi pada akhir masa kontrak yang telah disepakati dengan pihak Lessor.

Selain dilihat dari present value cash outflow, dilihat juga dari efisiensi dalam pembayaran pajak penghasilan badan. Perbandingan penghematan pajak penghasilan badan disajikan pada tabel berikut.

Tabel 3

Selisih Total Efisiensi Pajak Penghasilan Badan (Penyusutan Metode Garis Lurus)

\begin{tabular}{|c|c|}
\hline Sumber Pendanaan & $\begin{array}{c}\text { Total Penghematan } \\
\text { Pajak Penghasilan }\end{array}$ \\
\hline Leasing & Rp 124.117.390 \\
\hline Pinjaman Bank & $\operatorname{Rp~80.112.314~}$ \\
\hline Selisih & Rp 44.005.075 \\
\hline
\end{tabular}

Sumber: Data diolah Penulis, 2015.

Pengaruh pajak pada alternatif leasing yaitu didapat dari angsuran setiap bulan dikalikan dengan tarif pajak penghasilan badan sebesar 25\%. Total penghematan pajak alternatif leasing selama masa sewa adalah sebesar Rp 124.117.390. Sedangkan pada pinjaman bank penghematan diperoleh dari bunga yang dibayarkan setiap bulan dan penyusutan aset tetap menggunakan metode garis lurus dikalikan dengan tarif pajak penghasilan badan sebesar $25 \%$. Total penghematan pajak alternatif pinjaman bank atas penyusutan metode garis lurus adalah sebesar $\mathrm{Rp}$ 80.112.314. Berdasarkan tabel hasil perhitungan terlihat bahwa penghematan pajak pendanaan alternatif leasing lebih besar daripada alternatif pinjaman bank atas penyusutan metode garis lurus, selisih dari penghematan pajak tersebut sebesar Rp 44.005.075.

Tabel 4

Selisih Total Efisiensi Pajak Penghasilan Badan (Penyusutan Metode Saldo Menurun)

\begin{tabular}{|c|c|}
\hline Sumber Pendanaan & $\begin{array}{c}\text { Total Penghematan } \\
\text { Pajak Penghasilan }\end{array}$ \\
\hline Leasing & Rp 124.117.390 \\
\hline Pinjaman Bank & Rp 118.345.517 \\
\hline Selisih & Rp 5.771.872 \\
\hline
\end{tabular}

Sumber: Data diolah Penulis, 2015. 
Total penghematan pajak alternatif leasing selama masa sewa adalah sebesar Rp 124.117.390. Sedangkan total penghematan pajak alternatif pinjaman bank atas penyusutan metode saldo menurun adalah sebesar Rp 118.345.517. Berdasarkan tabel hasil perhitungan diatas, terlihat bahwa penghematan pajak selama masa sewa pendanaan alternatif leasing lebih besar daripada alternatif pinjaman bank atas penyusutan metode saldo menurun, selisih dari penghematan pajak tersebut adalah sebesar $\mathrm{Rp}$ 5.771.872.

\section{Penutupan}

\subsection{Simpulan}

Berdasarkan hasil penelitian dan pembahasan yang telah dilakukan sebelumnya, maka Penulis memberikan simpulan mengenai analisis perbandingan pendanaan aset tetap alternatif leasing dengan pinjaman bank dalam efisiensi pajak penghasilan badan (Studi Kasus pada PT Cahaya Gasdom). Maka dapat diperoleh kesimpulan sebagai berikut:

1. Kebijakan pendanaan atas aset tetap pada PT. Cahaya Gasdom.

PT. Cahaya Gasdom telah menerapkan alternatif leasing khususnya (financial lease) dalam pendanaan aset tetap yang dibutuhkan. PT Cahaya Gasdom melakukan pendanaan aset tetap melalui leasing terakhir dilakukan untuk pembelian kendaraan Truk Mitshubishi F 8837 GM pada tahun 2014 dengan lessor yaitu PT Dipostar Finance yang beralamat di Gedung Sentrowal Senayan II Lantai 3 dan 4, Jalan Asia Afrika No.8 Jakarta. PT Cahaya Gasdom berencana menambah armada kendaraan untuk distribusi berupa 2 unit Truk
Mitshubishi Diesel FE SHD-X dan 1 unit Pick Up Mitsubishi Colt L300.

2. Perbedaan pendanaan aset tetap aternatif leasing dengan pinjaman bank.

Berdasarkan informasi yang diperoleh, pengadaan kendaraan untuk distribusi berupa 2 unit Truk Mitshubishi Diesel FE SHD-X dan 1 unit Pick Up Mitsubishi Colt L300 membutuhkan dana Rp 752.900.000. Perbandingan total present value cash outflow alternatif leasing lebih kecil dari pada pinjaman bank sehingga pendanaan alternatif leasing lebih menguntungkan dari pada pendanaan alternatif pinjaman bank baik penyusutan metode garis lurus maupun saldo menurun.

PT Cahaya Gasdom akan menghemat present value cash outflow sebesar Rp 46.819 .503 apabila menggunakan pendanaan alternatif leasing dibanding dengan pendanaan alternatif pinjaman bank atas penyusutan metode garis lurus. Present value cash outflow alternatif leasing lebih kecil dari pada pinjaman bank atas penyusutan metode saldo menurun sehingga pendanaan alternatif leasing lebih menguntungkan dari pada pendanaan alternatif pinjaman bank atas penyusutan metode saldo menurun. PT Cahaya Gasdom akan menghemat pengeluaran sebesar Rp 10.461.410 apabila menggunakan pendanaan alternatif leasing.

Selisih yang muncul dari hasil perbandingan antara leasing dengan pinjaman bank dipengaruhi oleh beberapa faktor diantaranya perbedaan angsuran, bunga, perbedaan pengaruh pajak serta kewajiban perusahaan membayar hak 
opsi pada akhir masa kontrak yang telah disepakati dengan pihak Lessor.

3. Efisiensi pajak penghasilan badan.

Pengaruh pajak pada alternatif leasing yaitu penghematan pajak langsung dikalikan dengan angsuran setiap bulan yaitu angsuran setiap bulan dikalikan dengan tarif pajak penghasilan badan sebesar $25 \%$. Total penghematan pajak alternatif leasing adalah sebesar Rp 124.117.390. Sedangkan pada pinjaman bank penghematan diperoleh dari bunga yang dibayarkan setiap bulan dan penyusutan aset tetap dikalikan dengan tarif pajak penghasilan badan sebesar 25\%. Total penghematan pajak alternatif pinjaman bank atas penyusutan metode garis lurus adalah sebesar Rp 80.112.314. Sedangkan total penghematan pajak alternatif pinjaman bank atas penyusutan metode saldo menurun adalah sebesar Rp 118.345.517.

Berdasarkan hasil perhitungan terlihat bahwa penghematan pajak pendanaan alternatif leasing lebih besar daripada alternatif pinjaman bank, baik penyusutan dengan metode garis lurus ataupun penyusutan dengan metode saldo menurun ganda, selisih dari penghematan pajak tersebut adalah sebesar $\mathrm{Rp}$ 44.005.075 dan Rp 5.771.872.

\subsection{Saran}

Berdasarkan kesimpulan diatas, maka Penulis menyampaikan beberapa saran sebagai berikut:

\section{Bagi Perusahaan}

Karena PT Cahaya Gasdom sudah menerapkan alternatif leasing dalam pendanaan aset tetapnya, maka perusahaan sudah memilih alternatif pendanaan aset tetap yang terbaik bagi perusahaan. Selin itu alternatif leasing juga memiliki beberapa keuntungan dibandingkan dengan alternatif pinjaman bank. Oleh karena itu penerapan alternatif leasing dalam pendanaan aset tetap disarankan untuk terus diterapkan di Perusahaan.

Pemilihan perusahaan leasing dan bank harus diperhatikan karena perubahan penawaran seperti besarnya bunga dan sistem pengenaan bunga sangat berpengaruh pada hasil analisis total present value cash outflow. Besarnya bunga pada leasing mempengaruhi besar kecilnya present value cash outflow, sedangkan pendanaan pinjaman bank besarnya bunga dan penyusutan sangat berpengaruh terhadap besar kecilnya nilai present value cash outflow. Jadi sebaiknya PT Cahaya Gasdom mencermati dan memilih penawaran leasing yang memberikan bunga dan sistem pengenaan bunga paling menguntungkan bagi Perusahaan.

2. Bagi Perusahaan Leasing dan Bank

Perusahaan leasing hendaknya lebih mempromosikan produk-produk jasa sewa guna usaha kepada pengusaha, khususnya pengusaha menengah kebawah. Bank untuk jenis kredit tertentu seperti pinjaman untuk kepentingan usaha sebaiknya lebih memperhitungkan bunga.

3. Bagi Peneliti Selanjutnya

Penelitian ini hanya melakukan penelitian alternatif pendanaan leasing dengan pinjaman bank. Penelitian akan lebih lengkap dan valid apabila ada perbandingan dengan pendanaan yang lainnya, seperti aset tetap yang diperoleh dari penerbitan saham atau obligasi unuk perusahaan go public.

\section{Daftar Pustaka}

Agus Harjito dan Martono. 2012. Manajemen Keuangan. Ekonisia. Yogyakarta. 
Chairil Anwar Pohan. 2013. Manajemen Perpajakan. Gramedia Pustaka Utama, Jakarta.

Dewan Standar Akuntansi Keuangan Ikatan Akuntan Indonesia. 2013. Standar Akuntansi Keuangan. Ikatan Akuntan Indonesia, Jakarta.

Direktorat Jendral Pajak. 2013. Susunan Dalam Satu Naskah UndangUndang Perpajakan. Direktorat Penyuluhan, Pelayanan, dan Hubungan Masyarakat. Jakarta.

Erly Suandy. 2011. Perencanaan Pajak. Edisi 4. Salemba Empat. Jakarta.

Hery. 2014. Akuntansi Perpajakan. PT Grasindo. Jakarta.

Kasmir. 2013. Bank dan Lembaga Keuangan Lainnya. Rajawali Pers. Jakarta.

Nurwidiantmo. 2011. Kompilasi Bidang Hukum Tentang Leasing. Badan Pembinaan Hukum Nasional Kementerian Hukum dan Hak Asasi Manusia RI. Jakarta.

Siti Resmi. 2014. Perpajakan: Teori dan Kasus. Salemba Empat. Jakarta.

Sophar Lumbartoruan. 2006. Akuntansi Pajak. Grasindo. Jakarta

Syamsul Iskandar. 2013. Akuntansi Perbankan Dalam Rupiah Dan Valuta Asing. In Media, Jakarta.

Waluyo. 2013. Akuntansi Perpajakan. Salemba Empat. Jakarta

Renita Rumuy. 2013. Penerapan Perencanaan Pajak Penghasilan Badan sebagai Upaya Efisiensi Pembayaran Pajak PT Sinar Sasongko. STIE MDP.

Republik Indonesia. Keputusan Menteri Keuangan No.: 1169/KMK.01/1991 tentang Kegiatan Sewa Guna Usaha (Leasing).

Republik Indonesia. Peraturan Menteri Keuangan Nomor 96/PMK/PMK.3/2009 tentang Jenis-Jenis Harta Yang Termasuk Dalam Kelompok Harta Berwujud
Bukan Bangunan Untuk Keperluan Penyusutan.

Republik Indonesia. Undang-Undang

Nomor 36 Tahun 2008 tentang

Pajak Penghasilan.

Republik Indonesia. Surat Ketetapan

Bersama 3 Menteri: No. Kep122/MK/2/1974,

No32/M/SK/2.1974, dan

No.30/Kbp/I/1974. tentang

Perizinan Usaha Leasing.

Republik Indonesia. Peraturan Otoritas

Jasa Keuangan Nomor

29/POJK.05/2014 tentang

Penyelenggaraan Usaha

Perusahaan Pembiayaan.

Republik Indonesia. Undang-Undang Nomor 10 Tahun 1998 tentang Perbankan. 